\title{
Bioinformatic and molecular investigation of Sirt3 expression
}

\author{
F Kyle Satterstrom ${ }^{1,2,3^{*}}$, William R Swindell ${ }^{4,5}$, Martha L Bulyk $k^{5,6,7}$, Marcia C Haigis ${ }^{2,3}$ \\ From Metabolism, diet and disease \\ Washington, DC, USA. 29-31 May 2012
}

\section{Background}

Fasting and calorie restriction cause significant metabolic changes as organisms try to maintain energy homeostasis. The mitochondrial $\mathrm{NAD}^{+}$-dependent protein deacetylase Sirt3 has important metabolic effects, including promotion of fatty acid oxidation during fasting [1] and repression of glycolysis in cancer cells [2]. We sought to investigate the mechanisms by which Sirt3 is transcriptionally induced and regulated using both bioinformatic and molecular methods.

\section{Materials and methods}

Our approach was two-pronged: using the DNA sequence analysis program PhylCRM [3], we analyzed the regulatory sequences of Sirt3 and genes with similar expression profiles to determine over-represented transcription factor binding sequences. We also conducted a quantitative realtime PCR-based targeted screen in HEK 293T cells to determine the effects of calorie restriction mimetic drugs on Sirt3 expression levels.

\section{Results}

We have identified candidate transcription factors that may affect Sirt3 expression levels, including the zinc finger transcription factor MZF1. We have also analyzed the effect of several drugs on Sirt3 expression, notably observing a decrease in Sirt3 expression with resveratrol treatment.

\section{Conclusions}

We have identified transcription factors and calorie restriction mimetic drugs which may control Sirt3 expression and are currently conducting follow-up studies.

'Harvard School of Engineering and Applied Sciences, Cambridge, MA 02138, USA

Full list of author information is available at the end of the article

\section{Author details}

'Harvard School of Engineering and Applied Sciences, Cambridge, MA 02138, USA. ²Department of Cell Biology, Harvard Medical School, Boston, MA 02115, USA. ${ }^{3}$ The Paul F. Glenn Labs for the Biological Mechanisms of Aging, Harvard Medical School, Boston, MA 02115, USA. ${ }^{4}$ Department of Genetics, Harvard Medical School, Boston, MA 02115, USA. ${ }^{5}$ Division of Genetics, Department of Medicine, Brigham and Women's Hospital and Harvard Medical School, Boston, MA 02115, USA. ${ }^{6}$ Department of Pathology, Brigham and Women's Hospital and Harvard Medical School, Boston, MA 02115, USA. ${ }^{7}$ Division of Health Sciences and Technology, Harvard Medical School, Boston, MA 02115, USA.

Published: 1 June 2012

\section{References}

1. Hirschey MD, Shimazu T, Goetzman E, Jing E, Schwer B, Lombard DB, Grueter CA, Harris C, Biddinger S, Ilkayeva OR, Stevens RD, Li Y, Saha AK, Ruderman NB, Bain JR, Newgard CB, Farese RV Jr, Alt FW, Kahn CR, Verdin E: SIRT3 regulates mitochondrial fatty-acid oxidation by reversible enzyme deacetylation. Nature 2010, 464(7285):121-5.

2. Finley LW, Carracedo A, Lee J, Souza A, Egia A, Zhang J, Teruya-Feldstein J, Moreira PI, Cardoso SM, Clish CB, Pandolfi PR, Haigis MC: SIRT3 opposes reprogramming of cancer cell metabolism through HIF1a destabilization. Cancer Cell 2011, 19(3):416-28.

3. Warner JB, Philippakis AA, Jaeger SA, He FS, Lin J, Bulyk ML: Systematic identification of mammalian regulatory motifs' target genes and functions. Nat Methods 2008, 5(4):347-53.

doi:10.1186/1753-6561-6-S3-P40

Cite this article as: Satterstrom et al:: Bioinformatic and molecular investigation of Sirt3 expression. BMC Proceedings 2012 6(Suppl 3):P40.

Submit your next manuscript to BioMed Central and take full advantage of:

- Convenient online submission

- Thorough peer review

- No space constraints or color figure charges

- Immediate publication on acceptance

- Inclusion in PubMed, CAS, Scopus and Google Scholar

- Research which is freely available for redistribution

\section{() Biomed Central}

